\title{
Lymphoid stromal reaction in gastrointestinal lymphomas: immunohistochemical study of 14 cases
}

\author{
ANNE JARRY, ${ }^{*}$ NICOLE BROUSSE,${ }^{*} \dagger$ ANNY SOUQUE, ${ }^{*}$ JANINE BARGE, \\ G MOLAS, $\uparrow$ F POTET* $\dagger$
}

From *Biologie et Physiologie des Cellules Digestives INSERM U239, Faculté de Médecine X, Bichat, Paris, the †Service d'Anatomie et de Cytologie Pathologiques, Hôpital Beaujon, Clichy, France, and $\ddagger$ Service d'Anatomie Pathologique, Hôpital Louis Mourier, Colombes, France

SUMMARY The lymphoid stromal reaction, particularly the $\mathrm{T}$ lymphoid reaction, was studied immunohistochemically on cryostat sections in 14 cases of primary gastrointestinal B lymphomas, and compared with the type and distribution of lymphoid cells in three cases of gastric lymphoid hyperplasia. A pronounced T lymphoid reaction, mainly of the $\mathrm{T}$ helper phenotype, occurred in both lesions. Most of these T cells bore HLA-DR antigens, but only a few of them had the receptor for interleukin 2. The $T$ lymphoid reaction was observed inside the lymphomas in seven of a total of 14 cases, and around the lymphomas in four of the six cases clinically classified as stage I. Perivascular mucosal and submucosal nodules, entirely composed of $\mathrm{T}$ cells, seemed characteristic of gastric lymphoid hyperplasias. A T lymphoid reaction in lymphoid hyperplasias suggests an amplification of the cell mediated immune response; in lymphomas it could represent a host reaction against the lymphomatous infiltrate, therefore favouring a better prognosis.

Lymphoid cells in the gastrointestinal tract (GIT), as in lymph nodes, consist of B and $\mathrm{T}$ cells interacting with one another, helped by macrophages, during immune responses. This interaction has been studied in normal, hyperplastic, and lymphomatous lymph nodes with immunohistochemical techniques that permit the characterisation and localisation of $\mathbf{B}$ and $T$ cells in situ. ${ }^{1-5}$ In the normal and inflammatory GIT of laboratory animals ${ }^{6}$ and $\operatorname{man}^{7-9}$ lymphocytes and their subpopulations have also been identified by monoclonal antibodies. In lymphomas of the GIT, the most common being extranodal non-Hodgkin's lymphomas, ${ }^{10-11}$ the immunological phenotype of lymphomatous cells has been determined, ${ }^{12-14}$ but little attention has been paid to the lymphoid stromal reaction.

We aimed to study the lymphoid stromal reaction in gastrointestinal B lymphomas by using immunoperoxidase methods of frozen sections, and to compare this with the type and distribution of lymphoid cells in gastric lymphoid hyperplasias.

Material and methods

Biopsy and surgical specimens were collected at

Accepted for publication 30 January 1987
Beaujon and Louis Mourier Hospitals between 1984 and 1986.

LYMPHOMAS

Biopsy and surgical specimens of 14 cases of adult primary gastrointestinal non-Hodgkin's lymphoma were studied (table 1). The lymphomas were classified according to the non-Hodgkin's Lymphoma Pathologic Classification Project ${ }^{15}$ and to the modified Ann Arbor staging classification modified by Musshof. ${ }^{16}$ A laparotomy was performed in 11 cases; three 의 underwent only biopsies; six cases were classified as stage I, two as stage II, and three as stage IV with bone marrow disease (table 2). Most GIT lymphomas were of large cell type (table 1). All the lymphomas o studied were of B cell origin. The immunological $N$ phenotype most commonly expressed was IgM, $\mathrm{K}$ N (10 of 14 cases). The other phenotypes observed were IgM, $\lambda$ (one case); IgG,K (two cases); IgA (one case).

LYMPHOID HYPER PLASIAS

The three cases of focal gastric lymphoid hyperplasia were associated with a peptic ulcer. Gastric lymphoid hyperplasia was defined by the following morphological criteria: prominent mucosal B follicles with germinal centres, associated with a polymorphous infiltrate made of small lymphocytes, eosinophils, 
Table 1 Histological type of gastrointestinal B lymphomas

\begin{tabular}{llll}
\hline & Stomach & $\begin{array}{l}\text { Small } \\
\text { intestine }\end{array}$ & Colon \\
\hline $\begin{array}{l}\text { Follicular: } \\
\text { Small cell type }\end{array}$ & 1 & 0 & 1 \\
$\begin{array}{l}\text { Diffuse: } \\
\text { Small cell type }\end{array}$ & 3 & 0 & 0 \\
Large cell type & 8 & 1 & 0 \\
Total No & 12 & 1 & 1 \\
\hline
\end{tabular}

plasma cells, and histiocytes. The lymphocytes located between the crypts were non-invasive.

\section{TISSUE PROCESSING}

The endoscopic biopsy and surgical specimens were fixed in Bouin's solution, embedded in paraplast or paraplast-piccolyte ${ }^{17}$; sections $2 \mu \mathrm{m}$ thick were stained with hematoxylin and eosin, Giemsa, periodic acid Schiff, and by the Gordon and Sweet's method for reticulin.

Some fragments of the tissues studied were snap frozen in isopentane in liquid nitrogen. Cryostat sections $5 \mu \mathrm{m}$ thick were gathered on glass slides, air dried for at least two hours, fixed in acetone for 10 minutes, and stored at $-20^{\circ} \mathrm{C}$ until use.

\section{IMMUNOHISTOCHEMICAL PROCEDURES}

A three stage indirect immunoperoxidase method according to Stein et al $^{18}$ was applied on cryostat sections, which were incubated with monoclonal antibodies directed against lymphoid B and $T$ cells and histiocytes (table 3), then with rabbit antimouse and swine antirabbit antisera conjugated to horseradish

Table 3 Monoclonal antibodies
Table 2 Clinical staging of 11 cases of lymphomas with laparotomy

\begin{tabular}{lll}
\hline Stage & Diffuse lymphomas & Follicular lymphomas \\
\hline I & 6 & 0 \\
II & 2 & 0 \\
IV & 1 & 2 \\
Total No & 9 & 2 \\
\hline
\end{tabular}

peroxidase (Dakopatts A/S, Copenhagen, Denmark). Peroxidase activity was shown, as described by Graham and Karnovsky. ${ }^{19}$ Nuclei were counterstained with haematoxylin.

A double immunostaining technique according to Mason and Sammons, ${ }^{20}$ was performed to allow the identification of two different cell types in the same frozen section. In addition, a peroxidaseantiperoxidase method according to Sternberger et $a^{21}$ was performed on deparaffinised sections, with polyclonal antibodies directed to Ig light and heavy chains (Miles Scientific, Paris, France).

\section{ESTIMATE OF T CELL NUMBERS}

Although accurate quantitation was difficult in tissue sections and no quantimetric study was performed, it was possible to estimate $T$ cell population in $B$ cell lymphomas by scanning the slides with a $\times 10$ objective. The degree of $T$ cell infiltration among neoplastic B cells was arbitrarily graded as mild, moderate, or severe. An estimate of the CD4:CD8 ratio was made by comparing two serial sections stained by CD4 and CD8 antibodies. The slides were reviewed by two different observers (AJ, NB).

\begin{tabular}{llll}
\hline Monoclonal antibodies & Dilution & Specificity & Source \\
\hline Pan B (CD22) & $1 / 25$ & All B cells & Dakopatts \\
Pan B & $1 / 700$ & All B cells & Miles Scientific \\
Ig G & $1 / 100$ & $\gamma$ heavy chain & Miles Scientific \\
Ig A & $1 / 100$ & $\alpha$ heavy chain & Miles Scientific \\
Ig M & $1 / 25$ & $\mu$ heavy chain & Dakopatts \\
Ig D & $1 / 25$ & $\delta$ heavy chain & Dakopatts \\
Ig E & $1 / 100$ & $\varepsilon$ heavy chain & Miles Scientific \\
$\kappa$ & $1 / 100$ & $\kappa$ light chain & Becton-Dickinson \\
$\lambda$ & $1 / 100$ & $\lambda$ light chain & Becton-Dickinson \\
Leu 4 (CD3) & $1 / 100$ & All T cells & Becton-Dickinson \\
Leu 1 (CD5) & $1 / 100$ & T cells, B cells of B chronic & Becton-Dickinson \\
& & lymphocytic leukaemia and of & \\
Leu 3a (CD4) & some B lymphomas & Becton-Dickinson \\
Leu 2a (CD8) & $1 / 100$ & Helper/inducer T cells and & Bistiocytes/macrophages \\
Leu 7 & $1 / 100$ & Suppressor/cytotoxic T cells & Becton-Dickinson \\
IOT 14 (CD25) & $1 / 100$ & Natural killer cells & Activated T cells \\
Leu M5 & $1 / 50$ & Tissue macrophages & Becton-Dickinson \\
HLA-DR & $1 / 100$ & Normal B lymphocytes; B cell & Becton-Dickinson \\
& $1 / 100$ & type lymphomas; histiocytes; & \\
& & activated T cells & \\
\hline
\end{tabular}

$\mathrm{CD}=$ clusters of differentiation. 


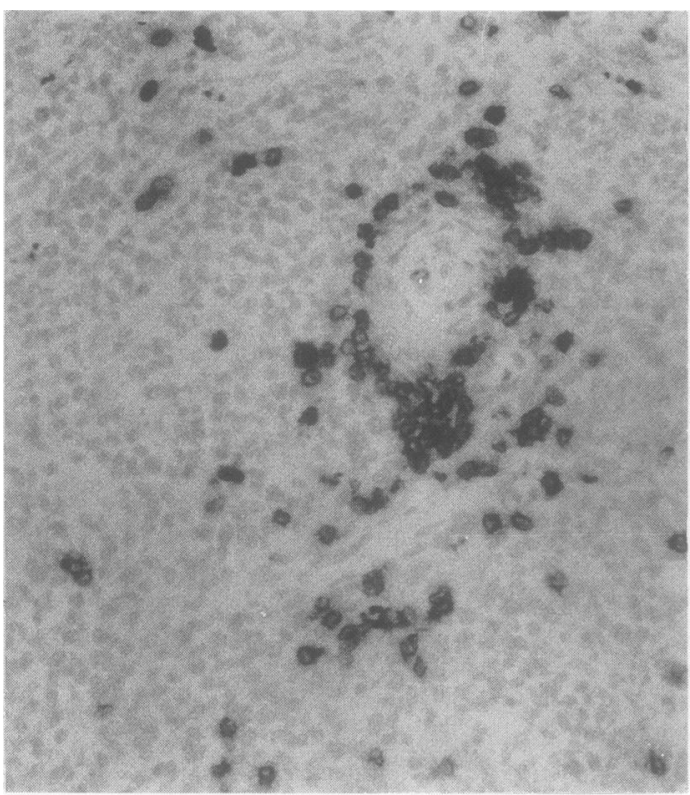

Fig 1 Cryostat section of diffuse large cell type gastric lymphoma stained with CD3 (Leu4). T cell infiltrate is predominant around blood vessels.

\section{Results}

NON-HODGKIN'S LYMPHOMAS

The stromal reaction included reactional $\mathrm{B}$ and $\mathrm{T}$ cells and histiocytes. It was studied inside and around the 12 diffuse lymphomas and the two follicular lymphomas.

$B$ cells The B lymphoid reaction was composed of intratumoral plasma cells and of extratumoral plasma cells and B follicles. Most of the mucosal B lymphocytes, as well as the B follicles, were HLA-DR positive.

Diffuse lymphomas Inside the 12 diffuse lymphomas IgM positive plasma cells predominated, irrespective of the tumour phenotype. These plasma cells were easily seen in the two IgG positive and in the one IgA positive lymphomas. In the $11 \mathrm{IgM}$ positive lymphomas IgM positive plasma cells were more apparent on paraffin sections, easily distinguishable from the nonlabelled lymphomatous cells. These plasma cells were polytypic, with a slight predominance of the light chain isotype, which differed from that of the lymphomatous cells. Around the diffuse lymphomas, in the lamina propria, a normal distribution of IgA positive and IgM positive plasma cells was found, with a slight increase in IgM positive plasma cells around blood vessels. Furthermore, a mucosal follicular lymphoid hyperplasia was observed around five gastric large cell type lymphomas.
Follicular lymphomas A few polytypic IgM positive $\stackrel{0}{*}$ and rare IgG positive plasma cells were seen inside the 으 lymphomatous follicles. In contrast, numerous poly- $\overrightarrow{\vec{F}}$ typic IgM positive and IgG positive cells were clus- $\stackrel{0}{\rightarrow}$ tered around blood vessels in the interfollicular areas.

$T$ cells

Diffuse lymphomas Inside the 12 diffuse lympho- $\stackrel{\mathbb{D}}{\circ}$ mas, the degree of $T$ cell infiltration (CD3 positive, CD5 positive) was pronounced in seven cases, and moderate in five. CD4 positive cells predominated in all the diffuse lymphomas (CD4:CD8 $=1 \cdot 5: 3) \cdot \vec{\omega}$ There were only a few Leu 7 positive cells. Some of the T cells were scattered among B cells, but much $\overline{0}$ more often clustered near the many capillaries irri- $\vec{\circ}$ gating the tumour (fig 1). Most T lymphocytes were HLA-DR positive, as assessed by a double immuno- $\checkmark$ staining technique using CD3 and anti-HLA-DR 8 antibodies. A few $\mathrm{CD} 25$ positive cells were found 음 inside the tumour in only four cases. Around the diffuse lymphomas, variable amounts of reactional $\mathrm{T} C$ cells, mainly CD4 positive cells, always fringed the neoplastic infiltrate. A strong T lymphoid reaction $\vec{\varphi}$ was packed around the tumour, showing its outline $\stackrel{\infty}{\vee}$ against the rest of the tissue, in four of the six cases of diffuse gastric lymphomas limited to the mucosa and submucosa and clinically classified as stage I (fig 2), but in none of the stage II and IV lymphomas. In two of the four cases showing a pronounced peritumoral $\stackrel{\varnothing}{\mathbb{D}}$ lymphoid infiltrate some cells were CD25 positive, but in lesser numbers than HLA-DR positive cells.

Follicular lymphomas Inside the lymphomatous follicles the $\mathrm{T}$ cell infiltration was mild, with a predominance of CD4 positive cells. In the interfollicular areas numerous $T$ cells, mainly CD4 positive, surrounded the lymphomatous follicles. There was no correlation between the degree of $T$ cell infiltration inside the lymphoma and the histochemical or architectural type of the lymphoma.

Histiocytes Histiocytes expressed LeuM5 and HLA-DR antigens. They were also recognisable by their cytoplasmic diffuse staining with CD4. These histiocytes were numerous inside the tumour in seven diffuse lymphomas and in one follicular lymphoma. $\stackrel{\circ}{\circ}$ There was no correlation between the histological $N$ grade of malignancy and the number of histiocytes $\stackrel{\sim}{\mathrm{N}}$ present inside the tumour. Histiocytes were numerous around the lymphoma in all cases.

\section{LYMPHOID HYPERPLASIAS}

Gastric lymphoid hyperplasias consisted of an increase in polytypic B cells, scattered or grouped in follicles, and in $T$ cells.

$B$ cells The B lymphoid hyperplasia comprised an increase in IgM positive and IgE positive plasma cells in the lamina propria, and of mucosal reactive $B$ fol- 

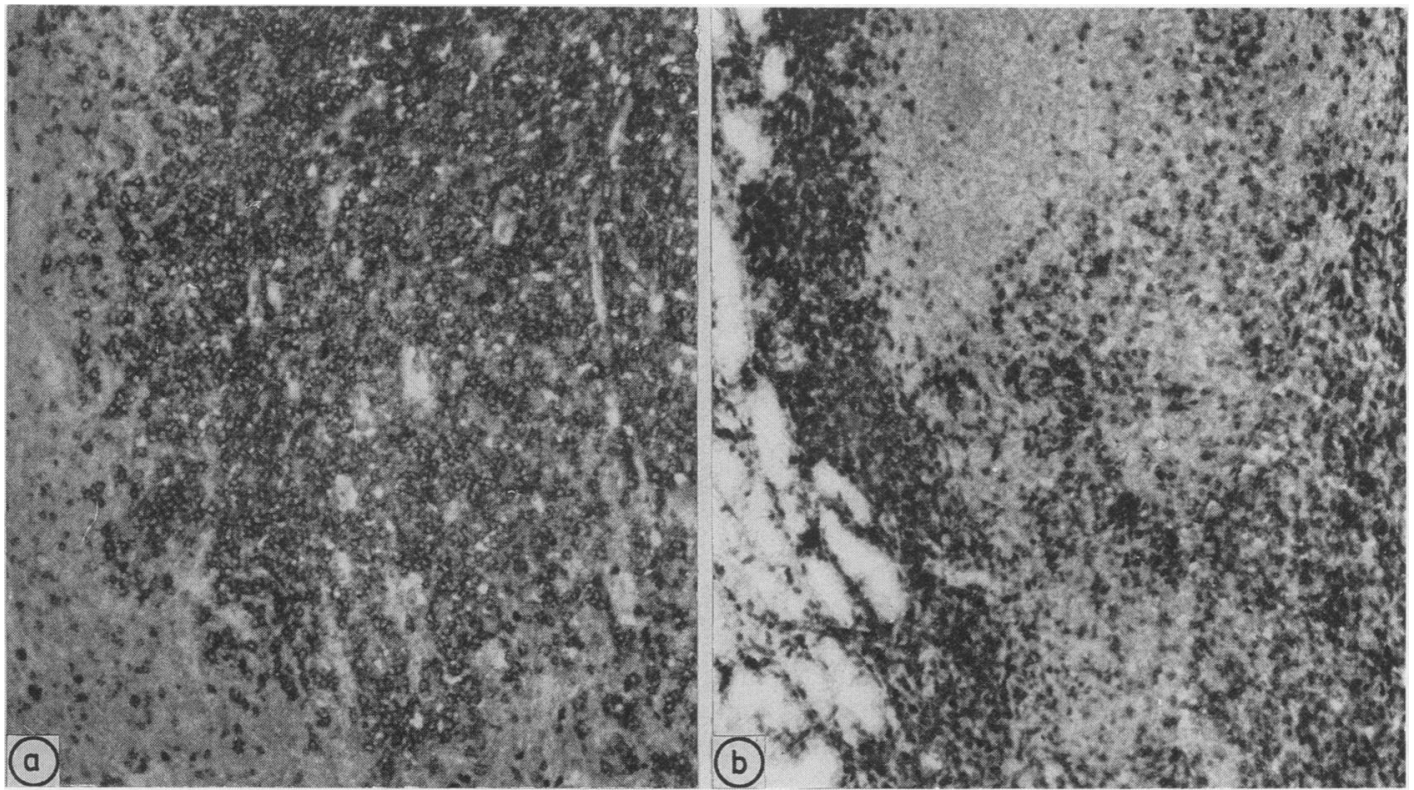

Fig 2 Cryostat sections of diffuse large cell type gastric lymphoma. Tumour infiltrate is strongly stained with anti-Pan B cell antibody $C D 22(a)$. Strong CD3 positive (Leu4 positive) $T$ lymphocyte reaction occurs on the periphery of lymphoma, and to a lesser degree, inside tumour itself $(b)$.

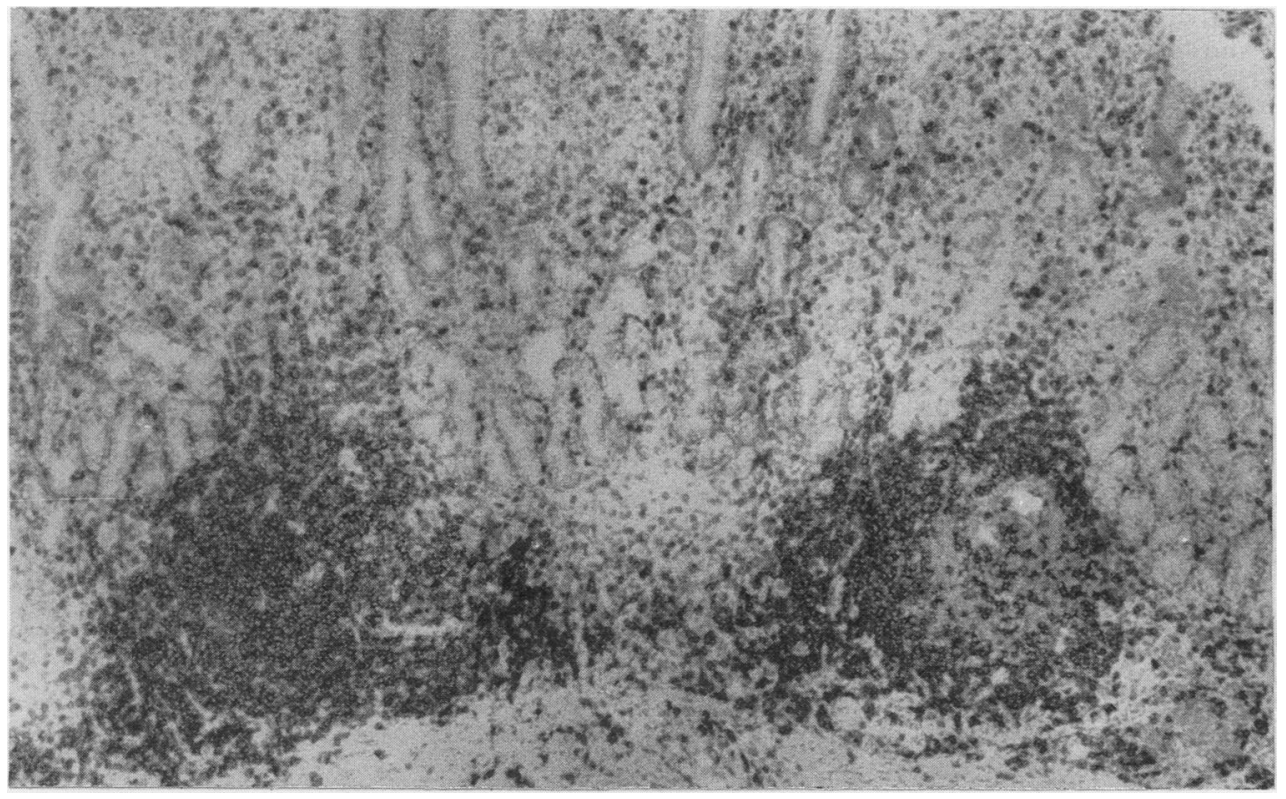

Fig 3 Cryostat section of gastric lymphoid hyperplasia stained with CD5 (Leu1). T cells are scattered in upper part of mucosa both in epithelium and in lamina propria, and massed around B follicle. Nodules of $T$ cells are also observed around blood vessels. 
licles, observed in the three gastric surgical specimens. The immunohistochemical staining of the B follicles was similar to that of the normal secondary lymph node follicles. The HLA-DR antibody stained mucosal B cells, scattered in the lamina propria or grouped in follicles.

$T$ cells No increase in the number of intraepithelial lymphocytes was seen, but lamina propria $\mathrm{T}$ lymphocytes were numerous and located around blood vessels and in the interfollicular areas. The CD4:CD8 ratio was $2: 1$ to $3: 1$ in all cases. Some lamina propria T lymphocytes, but rarely intraepithelial lymphocytes, bore HLA-DR antigens.

In the three cases of gastric lymphoid hyperplasia we noticed the presence of mucosal and submucosal nodules, entirely composed of $T$ cells, predominantly CD4 positive lymphocytes, and preferentially located around blood vessels (fig 3 ). A pronounced $T$ cell reaction also occurred around B follicles; some $T$ cells were present inside the germinal centres, as in normal lymphoid follicles. Most $\mathrm{T}$ cells of the $\mathrm{T}$ nodules, and some $T$ cells of the perifollicular areas were HLA-DR positive.

The CD25 antibody occasionally labelled isolated lymphocytes in the lamina propria, a few cells in the mantle zone of B follicles, and a few cells in the T nodules.

Histiocytes Histiocytes were localised in the upper part of the lamina propria, and to a lesser degree around $B$ follicles and $T$ nodules. They showed $a$ strong positivity for LeuM5 and anti-HLA-DR antibodies, and a more diffuse cytoplasmic staining with CD4.

\section{Discussion}

The study of adult primary B gastrointestinal nonHodgkin's lymphomas and gastric lymphoid hyperplasias showed an immune cell reaction composed of polytypic B cells, T cells, and histiocytes in both types of lesion.

The B lymphoid reaction occurring in lymphomas and in lymphoid hyperplasias is well recognised ${ }^{822}{ }^{23}$ It is composed of polytypic plasma cells, mainly IgM positive, preferentially located in perivascular areas, and of a B polytypic follicular lymphoid hyperplasia. This lymphoid hyperplasia may be associated with lymphomas, ${ }^{24}{ }^{25}$ and can be severe, as was observed in association with five of the 14 cases of gastrointestinal lymphomas studied. This B lymphoid reaction suggests the occurrence of a humoral immune response. ${ }^{26}$ The presence of $T$ cells, appearing both in gastrointestinal lymphoid hyperplasias and in B lymphomas, has not been reported previously.

A feature of lymphoid hyperplasia was the presence of mucosal and submucosal nodules entirely composed of T cells, mainly helper T cells. Some mucosal T nodules, localised near $B$ follicles, could have represented the extension of the $\mathrm{T}$ cell zone surrounding the follicles. The submucosal $\mathrm{T}$ nodules were located around vessels, without any B cell hyperplasia. This $T$ cell hyperplasia suggests an amplification of the cell mediated immune response in these benign lesions.

T cells had infiltrated B lymphomas inside and out in all the cases studied, whatever the histological type of lymphoma. Our results emphasise the correlation between the importance of $T$ cell reaction and a more favourable prognosis. It could be that the numerous $T$ cells, closely outlining the neoplastic infiltrate and separating it from the non-neoplastic zones, prevented the lymphomatous cells from spreading deeper in the muscular layers. This finding of clusters of $T$ cells around the tumour cells was observed in five of 23 cases of diffuse nodal lymphomas. ${ }^{4}$

The meaning of the $\mathrm{T}$ lymphoid stromal reaction in lymphomas remains a controversial point: $T$ cells, $\vec{c}$ which are predominantly helper $\mathrm{T}$ cells, may facilitate the neoplastic proliferation of B cells; or more probably, $T$ cells, preferentially located around blood vessels, could be regarded as reactional migrated $T$ cells and may represent a host reaction against the lymphomatous infiltrate, as postulated by most authors. $^{3-5}$ The latter hypothesis seems to be confirmed by the fact that most $\mathrm{T}$ cells located inside the lymphomas expressed HLA-DR antigens and that some of them, contrary to normal intestinal T cells, possessed the receptor for interleukin 2 , assessed by their positivity for CD25. ${ }^{27}$ These $T$ cells were thus activated and functionally mature $T$ cells which could specifically interact with lymphomatous B cells.

Assessing the importance of the lymphoid stromal reaction in gastric and rectal carcinomas, respectively, Watanabe et $a^{28}$ and $\mathrm{Jass}^{29}$ came to the conclusion that this reaction had a clinically important favourable postoperative prognosis. Similarly, a strong lymphoid stromal reaction in gastrointestinal lymphomas could favour a better prognosis. A long follow up of $D$ the patients studied, and a further study of a larger number of gastrointestinal lymphomas are likely to $N$ confirm the hypothesis that reactional $\mathrm{T}$ cells have an important immune regulatory role in gastrointestinal lymphomas of B cell type.

A Jarry is supported by a scholarship for the Association pour la Recherche sur le Cancer, Villejuif, 꾹 France. We thank Dr V Duchatelle for providing biopsy specimens; Mrs R Paris and M Perennec for excellent technical help; and Dr JY Scoazec for kindly reviewing the manuscript. 


\section{References}

1 Poppema S, Bhan AK, Reinherz EL, MacClusky RT, Schlossman SF. Distribution of T cell subsets in human lymph nodes. J Exp Med 1981;153:30-41.

2 Stein H, Bonk A, Tolksdorf G, Lennert K, Rodt H, Gerdes J. Immunohistologic analysis of the organization of normal lymphoid tissue and non-Hodgkin's lymphomas. $J$ Histochem Cytochem 1980;28:746-60.

3 Dvoretsky P, Wood GS, Levy R, Warnke RA. T lymphocyte subsets in follicular lymphomas compared with those in nonneoplastic lymph nodes and tonsils. Hum Pathol 1982;13:618-25.

4 Harris NL, Bhan AK. Distribution of T cell subsets in follicular and diffuse lymphomas of B cell type. Am J Pathol 1983;113:172-80.

5 Al Saati T, Caveriviere P, Brousse N, et al. Cells associated with the malignant clone in non-Hodgkin's lymphomas. Immunohistochemical study using monoclonal antibodies: new techniques and treatments. In: Sotto, Vrousos, Sotto, Vincent, eds. Non-Hodgkin's lymphomas. Fourth Cancer Researck Workshop, Grenoble. Basel: Karger, 1985:61-72.

6 Guy-Grand D, Griscelli C, Vassalli P. The mouse gut lymphocyte, as novel type of $T$ cell. Nature, origin and traffic in mice in normal and GVH conditions. J Exp Med 1978;148:1661-7.

7 Selby WS, Janossy G, Goldstein G, Jewell DP. T lymphocyte subsets in human intestinal mucosa: the distribution and relationship to MHC-derived antigens. Clin Exp Immunol 1981;44:453-8.

8 Nagura H, Kohler PF, Brown WR. Immunocytochemical characterization of the lymphocytes in nodular lymphoid hyperplasia of the bowel. Lab Invest 1979;40:66-73.

9 Arnaud-Battandier F. Le système lymphoide intestinal: conceptions actuelles. Gastroenterol Clin Biol 1984;8:632-40.

10 Brousse N, Foldes C, Barge J, Molas G, Potet F. Intérêt des biopsies endoscopiques dans le diagnostic des lymphomes malins primitifs de l'estomac: étude de 29 cas. Gastroenterol Clin Biol 1983;7:145-9.

11 Brooks JJ, Enterline HT. Primary gastric lymphomas. A clinicopathologic study of 58 cases with long-term follow-up and literature review. Cancer 1983;51:701-11.

12 Papadimitriou CS, Papacharalampous NX, Kittas C. Primary gastrointestinal malignant lymphomas. A morphologic and immunohistochemical study. Cancer 1985;55:870-9.

13 Grody WW, Weiss LM, Warnke RA, Magidson JG, Hu E, Lewin KJ. Gastrointestinal lymphomas. Immunohistochemical studies on the cell of origin. Am J Surg Pathol 1985;9:328-37.

14 Moore I, Wright DH. Primary gastric lymphoma: a tumour of mucosa-associated lymphoid tissue. A histological and immunohistochemical study of 36 cases. Histopathology 1984;8:1025-39.

15 The non-Hodgkin's lymphoma pathologic classification project: National Cancer Institute sponsored study of non-Hodgkin's lymphomas: summary and description of a working formulation for clinical usage. Cancer 1982;49:2112-35.

16 Musshoff K. Klinische stadieneinteilung der nicht-Hodgkin Lymphome. Strahlentherapie 1977;153:218-21.

17 Bogomoletz WV, Potet F. Paraplast-piccolyte double embedding. Its use for thinner sections in routine histopathologic examinations. Arch Pathol Lab Med 1981;105:670-3.

18 Stein H, Uchanska-Ziegler B, Gerdes J, Ziegler A, Wernet P. Hodgkin and Sternberg-Reed cells contain antigens specific to late cells of granulopoiesis. Int J Cancer 1982;29:283-90.

19 Graham RC, Karnovsky MJ. The early stages of absorption of injected horseradish peroxidase in the proximal tubules of the mouse kidney. Ultrastructural cytochemistry by a new technique. J Histochem Cytochem 1966;14:291-302.

20 Mason DY, Sammons RE. Alkaline phosphatase and peroxidase for double immunoenzymatic labelling of cellular constituents. $J$ Clin Pathol 1978;31:454-60.

21 Sternberger LA, Hardy PH, Cuculis JJ, Meyer HG. The unlabelled antibody enzyme method of immunohistochemistry. Preparation and properties of soluble antigenantibody complex (horseradish peroxidase-antihorseradish peroxidase) and its use in identification of spirochetes. $J$ Histochem Cytochem 1970;18:315-33.

22 Saraga P, Hurlimann J, Ozzello L. Lymphomas and pseudolymphomas of the alimentary tract. An immunohistochemical study with clinico-pathologic correlations. Hum Pathol 1981;12:713-23.

23 Matuchansky C, Rouchard G, Lemaire M, et al. Malignant lymphoma of the small bowel associated with diffuse lymphoid hyperplasia. N Engl J Med 1985;313:166-71.

24 Brooks JJ, Enterline HT. Gastric pseudolymphoma. Its three subtypes and relation to lymphoma. Cancer 1983;51:476-86.

25 Scoazec JY, Brousse N, Potet F, Jeulain JF. Focal malignant lymphoma in gastric pseudolymphoma. Histologic and immunohistochemical study of a case. Cancer 1986;57:1330-6.

26 Harris NL, Bhan AK. B-cell neoplasms of the lymphocytic, lymphoplasmacytoid, and plasma cell types: immunohistologic analysis and clinical correlation. Hum Pathol 1985;16:829-37.

27 Uchiyama T, Broder S, Waldmann TA. A monoclonal antibody (anti-Tac) reactive with activated and functionally mature human T cells. I- Production of anti-Tac monoclonal antibody and distribution of Tac + cells. J Immunol 1981;126:1393-403.

28 Watanabe H, Enjoji M, Imai T. Gastric carcinoma with lymphoid stroma. Its morphologic characteristics and prognostic correlations. Cancer 1976;38:232-43.

29 Jass JR. Lymphocytic infiltration and survival in rectal cancer. $J$ Clin Pathol 1986;39:585-9.

Requests for reprints to: Dr A Jarry, Faculté de Médecine X Bichat, Unité INSERM U239, 16 Rue H Huchard, 75018 Paris, France. 